\title{
Тектонофизический анализ южного берега Кандалакшского залива
}

Гордеев Н.А., Бондарь И.В.

ИФ3РАН, Москва, gord@ifz.ru, bond@ifz.ru

Аннотация. В ходе полевых исследований двух независимых экспедиций в 2019 году были собраны материалы геологических индикаторов деформаций с целью выяснения общей геодинамики и напряженнодеформированного состояния южного берега Кандалакшского грабена. В рамках данного исследования была произведена обработка всего имеющегося на данный момент тектонофизического полевого материала, сделано его описание и предпринята попытка анализа. Рядом тектонофизических методов произведена обработка полевых материалов и установлено, предварительно, что в пределах исследуемого района действуют (или действовали) три поля напряжения - северо-восточное сжатие, северо-западное сжатие и сдвиговое поле напряжения, вероятно с субширотными ориентировками оси максимального сжатия.

Ключевые слова: тектонофизика, южный берег Кандалакшского залива, Белое море, Кузокоцкий архипелаг, Керетский архипелаг.

\section{Tectonophysical analysis of the southern coast of the Kandalaksha Bay}

\section{Gordeev N.A., Bondar I.V.}

Schmidt institute of physics of the earth of the RAS, Moscow,gord@ifz.ru,bond@ifz.ru

\begin{abstract}
In the course of field investigation of two independent expeditions in 2019 materials of geological indicators of deformations were collected in order to clarify the general geodynamics and the stress-strain state of the southern coast of the Kandalaksha graben. Within the framework of this study, all the currently available tectonophysical field material was processed, its description was made, and an attempt was made to analyze it. A number of tectonophysical methods were used to process field materials and it was previously established that within the study area there are (or were) three stress fields - north-east compression, north-west compression and shear stress field, probably with sublatitudinal orientations of the axis of maximum compression.

Key words: tectonophysics, southern coast of the Kandalaksha Bay, White Sea, Kuzokotsky Archipelago, Keretsky Archipelago.
\end{abstract}

\section{Введение}

Полевыми отрядами в 2019 году были собраны обширные тектонофизические данные с целью выяснения общей геодинамики и напряженно-деформированного состояния южного берега Кандалакшского грабена. Эти локальные работы должны войти в состав работ по уточнению карт общего сейсмического районирования.

В рамках данного исследования была произведена обработка всего имеющегося на данный момент тектонофизического полевого материала, сделано его описание и предпринята попытка анализа. По разным причинам не везде удавалось собрать достаточное количество замеров, а также для обработки материалов использованы не все тектонофизические методы.

Для выяснения общей картины по геодинамике региона был проведен литературный анализ по исследованиям новейшей тектоники Кандалакшского грабена. Получен ряд схожих выводов, но также и выявлены пробелы в наших исследованиях.

\section{Методика}

Изучение избыточных горизонтальных напряжений проводилось с помощью метода катакластического анализа разрывных смещений Ю.Л. Ребецкого (Ребецкий и др., 2017). Для расчета использовалась программа STRESSgeol. Исходными данными для расчета являются полевые замеры пространственной ориентировки зеркал скольжения. Метод позволяет определить количественные характеристики реконструируемых локальных стресс-состояний: положение осей главных напряжений и коэффициент Лоде - Надаи. 
Структурно-парагенетический метод применен для анализа систем тектонической трещиноватости разных кинематических типов с их объединением в устойчивые структурные ассоциации (парагенезы) (Расцветаев, 1987). Малые разрывные нарушения, зеркала скольжения, отрывы, жилы и другие, используемые в данном методе геологические стресс-индикаторы, несут информацию о разных этапах деформирования.

Исследование распределения плотностей терщиноватости производилось в программе stereonet (stereonet.net). В качестве входных данных использовались ориентировки полюсов плоскостей трещиноватости - азимут и угол падения. Выходными данными являются азимуты простираний и углы падения плотности полюсов трещин и розы диаграммы по полюсам трещин. Эти данные позволяют проводить качественный анализ распределения трещиноватости и выявления трендов ее развития для установления парагенетических связей с региональными структурами.

\section{Результаты реконструкций}

В западной части исследуемого района методом катакластического анализа разрывных смещений получены 4 локальных стресс-состояния (рис. 1). В двух из них ось максимального сжатия ориентирована в северо-восточном направлении, южнее полуострова Киндо ось максимального растяжения ориентирована в северо-западном направлении, а ось максимального растяжения - в северо-восточном.

В районе островов Кузокоцкого архипелага рассчитано 6 локальных стресс-состояний. В большинстве из них ось максимального сжатия ориентирована в северо-восточном направлении. Ось максимального растяжения вертикальна. Только одно локальное стресс-состояние существенно отличается от других - ось максимального сжатия ориентирована субширотно, а ось максимального растяжения круто погружается в северном направлении.

На север от острова Великий на мысе Купчинницком получено локальное стресс-состояние, отвечающее растяжению - ось максимального сжатия практически вертикальна, а ось максимального растяжения и промежуточная ось - горизонтальны.

На север от острова Великий на мысе Купчинницком получено локальное стресс-состояние, отвечающее растяжению - ось максимального сжатия практически вертикальна, а ось максимального растяжения и промежуточная ось - горизонтальны.

В южной части исследуемого района удалось рассчитать два локальных стресс-состояния с похожим расположением оси максимального сжатия - погружение на юго-запад под углом $45^{\circ}$. В районе Малиновой Варакки ось максимального растяжения полого погружается на юго-восток под углом $15^{\circ}$, а промежуточная ось имеет субмеридиональную ориентировку. На о. Сидоров ось максимального растяжения расположена практически горизонтально, погружается на северо-запад, ось максимального сжатия и промежуточная ось под углом $35^{\circ}$ погружаются на юг и северо-восток соответственно.

С помощью структурно-парагенетического анализа малых структурных форм удалось получить следующие предварительные результаты. В западной части исследуемого района на полуострове Киндо фиксируется два локальных стресс-состояния с двумя почти противоположными ориентировками главных осей напряжения. В первом случае ось максимального сжатия ориентирована в юго-западном направлении (Ю3-СВ), а ось максимального растяжения - в северо-западном. Во втором случае ось максимального растяжения, вероятно, ориентирована в юго-западном направлении, ось максимального сжатия либо вертикальна, либо имеет северо-западную ориентировку.

У залива Красная губа согласно зеркалам скольжения со сбросовой кинематикой ось максимального растяжения ориентирована в субмеридиональном направлении или даже в северозападном. А ось максимального сжатия ориентирована в северо-восточном направлении.

На внешних островах Кузокоцкого архипелага также выделяется два локальных стресссостояния с различным положением главных осей напряжения. Как и на полуострове Киндо оси максимального сжатия ориентированы в северо-восточном направлении и в северо-западном направлении, оси максимального растяжения - соответственно. 


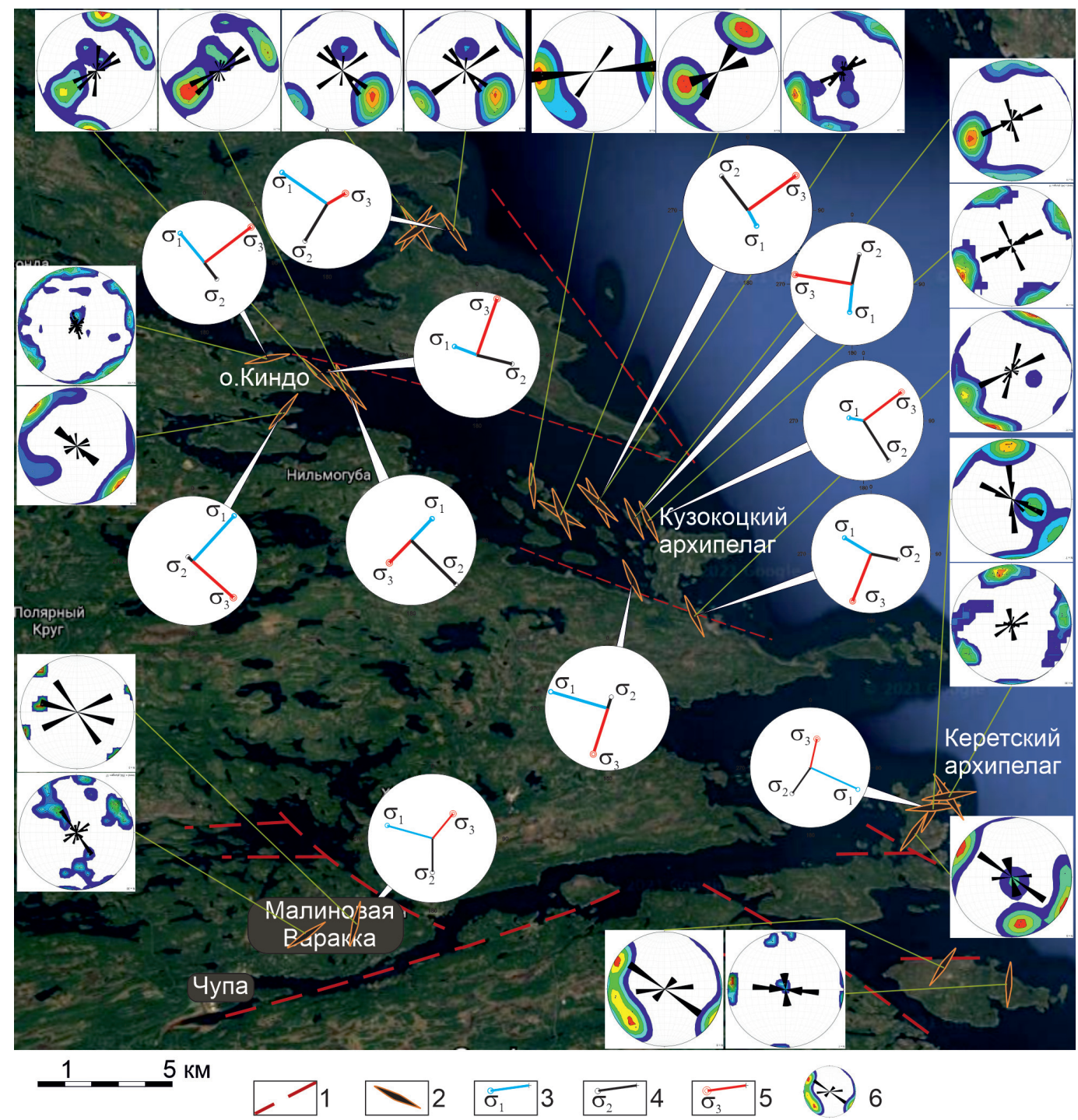

Рис. 1. Детальная карта-схема с реконструированными локальными стресс-состояниями на южный берег Кандалакшского залива. 1 - разломы по геологическим данным (геологическая..., 1959); 2 - максимум по простиранию трещин; 3-5 - главные оси напряжения (построения на верхнюю полусферу): 3 - ось горизонтального растяжения, 4 - промежуточная ось, 5 - ось горизонтального сжатия; 6 - диаграммы расчета в Stereonet, плотность по полюсам трещиноватости (построения на верхнюю полусферу).

Fig. 1. Detailed map with reconstructed local stress states on the southern shore of the Kandalaksha Bay. 1 - faults based on geological data (geological..., 1959); 2 - maximum among the strikes of fractures; 3-5 - main stress axes (construction on the upper hemisphere): 3 - maximum tension, 4 -intermediate, 5 - maximum compression; 6 - calculation diagrams in Stereonet, density by fracture poles (construction on the upper hemisphere).

На о. Великий в одной точке наблюдения зафиксированы малые структурные формы, соответствующие северо-западному положению оси максимального растяжения.

На о. Сидоров также фиксируется северо-западное растяжение, но при этом, возможно, есть следы второго локального стресс-состояния, с субмеридиональной ориентировкой оси максимального растяжения.

В районе Малиновой Варакки замеров немного (40, из них зеркал скольжения 5), однако есть основания предполагать, что ось максимального растяжения ориентирована в субширотном направлении.

Трещиноватость южного берега Кандалакшского залива не имеет единого тренда развития, однако отчетливо видна сгруппированность. Так, мы выделяем юго-восточную группу Чупин- 
ской губы и Керетского архипелага с ориентировками северо-восточного простирания трещин. Центральная группа в районе Кузокоцкого архипелага и пролива Великая Салма с общим трендом северо-западного простирания трещин. И на самом северном и северо-западном ограничении территории исследования возле окончания п-ова Киндо и о. Великий наблюдается третья группа северо-восточного простирания трещин. Подобное распределение трещиноватости вероятно связано с развитием оперяющих разрывов регионального масштаба в области динамического влияния Кандалакшского грабена.

\section{Обсуждение результатов}

Исследование Кандалакшского грабена и его обрамления активно ведется и другими научными группами. Исследователи находят следы тектонической активизации разного рода, например в работе Баранской А.В. (2015) по ледниковым осадкам восстановлен характер современных вертикальных движений, а уже на основании этого, а также согласно закартированным сейсмодислокациям получены локальные стресс-состояния на район Керетского и Кузокоцкого архипелагов, характеризующиеся как субширотное и восток-юго-восточное сжатия. Результаты этой работы идут в разрез с нашими реконструкциями и вопрос возраста реконструированных напряжений остается открытым.

В работе Николаевой С.Б. (2019) в районе п. Ковда в ходе палеосейсмологических исследований большое внимание уделялось изучению трещиноватости в сейсмогенных уступах. По общим трендам микротрещиноватости удалось установить, что для района Ковды характерны те же условия формирования трещиноватости, что и для северного обрамления о. Великий - происходит градиентный разворот в северо-восточном направлении, начиная от северо-западной окраины о. Киндо и вплоть до п. Ковды. А напряжения объясняются послеледниковой активизацией блоковой тектоники. Современные структуры образуются вследствие импульсных смещений блоков друг относительно друга. Наши реконструкции стресс-состояний согласуются с подобной концепцией развития новейшей тектоники, однако есть противоречия в структуре градиентного разворота трещиноватости, который не возможен в блоковой тектонике.

Совокупное объяснение развития Кандалакшского грабена описано в работе Колодяжного С.Ю. (2019). По результатам дистанционного и структурно-кинематического анализа авторы установили наличие нескольких этапов деформации - не менее четырех. А новейшая послеледниковая тектоника и вовсе характеризуется горизонтальным перемещением Кольского блока в юговосточном направлении с последующим вращением против часовой стрелки.

Нашей группой установлено наличие нескольких этапов деформаций структурнопарагенетическим методом. Устойчиво выделяются три поля напряжения, это северо-восточное и северо-западное сжатия, сдвиговое. Есть признаки различных комбинаций, но для их подтверждения требуется больше статистических данных. Однако наши исследования никак не выявляют вращательной компоненты послеледниковых деформаций.

\section{Заключение}

Таким образом, в ходе исследований были реконструированы ряд локальных стресс-состояний в районах Кузокоцкого и Керетского архипелагов, побережья Чупинской губы и пролива Великая Салма. По реконструкциям устанавливается общее поле напряжения северо-восточного сжатия для южного берега Кандалакшского грабена, однако в некоторых местах встречается субширотное и северо-западное сжатие. Также есть основания утверждать, что породы побережья Кандалакшского залива несут на себе следы как минимум трех этапов деформирования, соответствующих полям напряжения северо-восточного сжатия, северо-западного сжатия, а также сдвигового, вероятно с субширотной ориентировкой оси максимального сжатия.

Тем не менее, однозначных выводов делать пока нельзя, так как имеющихся данных не хватает для геодинамических реконструкций по территории. Для таких выводов необходимо исследование материковой части и расширение данных по архипелагам. 


\section{Литература}

1. Баранская А.В., Романенко Ф.А. Дифференцированные вертикальные движения и блоковая тектоника побережий Кандалакшского залива Белого моря // Материалы IV Международной научно-практической конференции молодых ученых и специалистов памяти академика А.П. Карпинского, 16-20 февраля 2015 г., Санкт-Петербург. ФГУП ВСЕГЕИ. - ВСЕГЕИ г. Санкт-Петербург. 2015. С. 3-6.

2. Геологическая карта: Q-36-XV. Геологическая карта СССР. Карельская серия, масштаб: 1:200000, серия: Карельская, составлена: Северо-Западное геологическое управление, 1959 г., редактор: Шуркин К.А.

3. Колодяжный С.Ю., Балуев А.С., Зыков Д.С. Структура и эволюция северо-запада БеломорскоСеверодвинской зоны сдвига в позднем Протерозое и Фанерозое (Восточно-Европейская платформа) // Геотектоника. 2019. №1. C. 62-86. doi: 10.31857/S0016-853X2019162-86.

4. Николаева С.Б. Послеледниковая тектоника и палеосейсмодислокации в районе участка Ковды (Кандалакшский залив Белого моря) // Вестник СПбГУ. Науки о Земле. 2019. Т. 64. (3). С. 434-453. doi: https:// doi.org/10.21638/spbu07.2019.304.

5. Расцветаев Л.М. Парагенетический метод структурного анализа дизъюнктивных тектонических нарушений // Проблемы структурной геологии и физики тектонических процессов. М.: ГИН АН СССР. 1987. С. 173-235.

6. Ребецкий Ю. Л., Сим Л. А., Маринин А. В. От зеркал скольжения к тектоническим напряжениям. Методы и алгоритмы. ГЕОС Москва. 2017. 225 с. 